Małgorzata Drwal

Malgorzata Drwal is affiliated to the Department of Modern Dutch/ Flemish Literature and South African Studies, University of Wrocław, Poland. E-mail: malgorzata.drwal@gmail.com

\section{A personal text owned by its public- changing readings of Sarah Raal's Met die Boere in die Veld}

\section{A personal text owned by its public-changing readings of Sarah Raal's Met die Boere in die Veld}

What seems to be a typical feature of Boer women's personal texts which refer to the Anglo-Boer War (1899-1902) is the militant rhetoric of protest against the British aggression. Met die Boere in die Veld ("With the Boers in the Veld") by Sarah Raal is a perfect example of this trend. Yet, her case is unique, because she actually spent a part of the war in the veld, fighting side by side with her brothers, which definitely was not a traditional place for a woman during a military conflict. Her memoirs were published for the first time in the 1930s, reprinted a number of times, and re-issued in 2000 in two language editionsAfrikaans and English (significantly under a new title, The Lady who Fought). An additional introduction was added to both new editions, which suggests a new role of the heroine and a new meaning of her story. This paper discusses how Raal's original foreword and the new introduction influence the reader's response to the text. Additionally, attention is drawn to the role of other paratextual elements of the book and the matter of translation. Having taken into account political and gender discourses operating as a context for every reading, the text undergoes re-interpretations. Consequently, the book, once an anti-British Afrikaner nationalist propaganda story, turns into a popular adventure tale about a brave Boer girl, a story about an exceptional woman, a proto-feminist who transgresses the conventional gender roles, or into a universal pacifist protest. In the 2000 edition pacifist and feminist aspects come to the foreground, and this way the old story becomes a suitable read for the modern post-apartheid reader. Keywords: Anglo-Boer War, life writing, reader's response, paratext, Sarah Raal.

During the Anglo-Boer War (1899-1902) Boer women turned out to be the most devoted patriots and most resolute bittereinders. Helen Bradford (50-51) suggests that it was to a great extent thanks to such women who were pushing their husbands and sons to fight till the bitter end that the war did not terminate with the British invasion of the Free State in February 1900. Living in the isolation of vast farms in the South African interior, the women formed a belief that the Englishman was an embodiment of all evil, and this conviction evolved into a kind of religion (Bradford 48). This finds confirmation in Boer women's personal texts such as diaries or memoirs, where their militant, anti-British attitude often comes to the foreground. Such texts offer an image of women of adamant will and strength who against all odds remain faithful to the values they believe in. 
Met die Boere in die Veld ("With the Boers in the Veld") by Sarah Raal is a perfect example of this trend. Yet, the story is worth having a closer look at for a couple of reasons. To start with, the book is by far the most popular account of a woman who stayed on commando for a longer period of time, and accompanied her brothers in the battlefield. The story, first published in Afrikaans as a series of contributions in the newspaper Die Burger, came out in a book form in 1938. Since then several editions have been issued; the latest one in 2000-significantly in two language versions: an Afrikaans reprint and for the first time an English translation. These newest editions contain an additional editor's introduction. Consequences of this addition and a comparison of the two language versions constitute the focus of this paper.

The publication in 2000 seems to have refreshed interest in Raal's story, since excerpts from the memoir can be found in The Closest of Strangers: South African Women's Life Writing by Judith Lutge Coullie published in 2004. The book provides a chronological record of the history of South Africa, divided into nine periods, each starting with a short sketch of the historical background, against which selected women's life writings are presented as re-telling the history from a woman's perspective. Coullie introduces Raal's wartime adventures as unique, and chooses a passage from the memoir where Sarah as a member of a Boer commando volunteers to scout for British troops. Therefore Raal comes across as a woman whose initiative and courage surpass those of her fellow men. She tells how terrified she felt, and yet how her pride did not let her resign, when she admits bluntly: "I didn't want them to lose their good opinion of me" (Raal qtd in Coullie 26).

The story has also been presented to the broad public in Lauren Beukes' Maverick: Extraordinary Women from South Africa's Past (2004), which, according to the author, is not a history book or a feminist manifesto, but "a sample smattering of just some of the most riveting and rollicking life stories" (9). In fact, both books stress women's participation in the history of South Africa and, significantly, focus on extraordinary female personalities. The character of these publications happens to be in tune with the new interpretation of the memoir as suggested in the introduction to its new edition, which is elaborated on later.

Helen Dampier in her PhD thesis devotes a considerable part of Chapter Six to the issue of the translation of Raal's account into English. While she focuses on the language, the aim of this paper is to broaden the analysis so that it embraces a comparison of the 1938 and two 2000 versions also on the level of what Gérard Genette referred to as paratext, i.e. introductions, titles as well as the graphic form of the book, its layout, cover art and illustrations. As Genette puts it, paratext is a kind of "undecided zone" through which the reader passes before they enter the text proper; it is - metaphorically speaking - a threshold that offers "a possibility of either stepping inside or turning back" (Genette 2). This is a space of transition and transaction between the author and the reader, and also a mechanism which transforms a text into a book; in other words, 
paratext ensures "the text's presence in the world, its 'reception' and consumption in the form [...] of a book" (1). Thus it is mainly paratext which determines the interpretation-a phenomenon which is essential for the discussion in this paper.

My point of departure is that there are some differences between various editions of the book-especially those between the 1938 and 2000 editions are conspicuous. The discrepancies between the two versions of 2000 seem to be less obvious, nevertheless they offer an equally interesting ground for investigation.

\section{Raal's story and her self-creation}

Raal's memoir embraces precisely the time of the war 1899-1902. The story starts in October 1899 when Sarah's brothers and father leave home to join a Boer commando, her mother and younger siblings are taken to a concentration camp, and Sarah is left alone on the farm. But she has to flee too, gets interned in the Springfontein camp, escapes shortly thereafter and joins her brothers on commando.

She bravely suffers hardships of the life in the veld. Yet, eventually when the commando gets betrayed and captured, she is sent to the Kroonstad concentration camp where she spends the last part of the war. When caught this time she is notorious among the British and her impertinency shown in exchanges with British soldiers is really striking. She is sent to the so-called bird's cage, solitary confinement, where she falls ill and almost dies. Luckily, she survives and after the war reunites with her family.

The book starts with a short authorial foreword (discussed in detail later) dated 1936. The author states that she relied on her memory while writing, so the gap in time clearly suggests that she could have taken some liberties with the past. When reading such an autobiographical narrative one needs to bear in mind that there is no unified "I", but the author as a historical person, the character in the book who bears the author's name, and the narrator are in fact separate facets of Sarah Raal (Smith and Watson 62-63). The Raal who writes is a middle-aged woman, and the Sarah-a young girl probably in her early 20 s is a creation for the needs of the narrative. Even though writing down memories might have been an attempt to reconstruct her past and as such has a personal dimension, it needs to be stressed that the memoir is also a construction. The story seems to be much more a self-creation and an adventure novel than a historical document. And indeed, Raal casts herself in the role of a young heroine who undertakes to prove herself. The simple, lively narrating style matches the story's subject matter, which focuses mainly on events. Yet, since it is told from Sarah's perspective, her thoughts and emotions, such as fear, anger and despair, are described as well, which gives the narration a clearly subjective colouring.

What seems to be symptomatic is that Sarah-the narrator admits openly before the reader that she was scared many times, but never showed it to her brothers or the Boers from the commando. 
In the heat of battle I would often laugh and cry at the same time, to fool my brothers-who worried about me so much-that there was no fear in me, for I never wanted to hinder the burghers by showing my fear. When in danger I usually sheltered my body as best I could, and after the battle I would speak as one who'd been in the thick of the fight. (Raal, Lady 54)

At times she strikes a bombastic tone, especially when she wishes to express her patriotism and accentuate that in all critical situations she chose the right thing to do. For instance having considered asking a befriended English officer for help, she concludes that such a move would be not worthy of a true patriot: "Then I felt ashamed for wanting to ask the enemy for help or mercy. [...] Should I ask the enemy for mercy now, possibly in my last hours? No, never! If I had to die, I would die an Afrikaner, faithful unto death" (Raal, Lady 91-92).The account of fights and wanderings around the veld is interspersed with short emotional fragments, where Sarah describes her doubts and conflicting feelings when confronted with war reality. She seems to be baffled by her own sympathy for the enemy, when observes a young soldier-boy who wipes the blood off the face of his dead brother: "'Oh, I promised mother I'd look after you, what am I to do now?' With that all my joy disappeared, and I cried with the Englishman. They were both so young and looked so innocent" (Raal, Lady 55-56).

The young Sarah's typical trait is her uncompromising attitude which can be best traced in dialogues. While interrogated she clearly mocks the officers; she is sarcastic and rebellious, and openly speaks her disdain of the enemy:

"What did you actually do in the veld?"

"Oh, nothing special. We just killed English, or captured them, and 'shook them out'!" I replied.

"And you told us you were in the Red Cross!" he exclaimed. (Raal, Lady 73)

Dialogues function as a tool to characterize not only Sarah, but also the British. The manner in which they speak leaves no doubt that they are cruel and see the Boers as inferior: "What are you talking about, you Dutch bastard? Come out!" (Raal, Lady 66). The dialogues are at times clearly exaggerated, which makes Sarah only a more attractive character. This, too, testifies to Raal's self-creation as a rebellious cow-girl-a heroine very appealing to the reader.

\section{The adventure story pattern}

Susanne Egan in Patterns of Experience in Autobiography (1984) notices that all autobiographical texts belonging to the Western culture follow a limited number of structural patterns, yet allowing for some variations. These patterns of experience are based on metaphors, since metaphors constitute a universal medium of organizing 
experience and investing it with meaning. Autobiography has adopted the metaphor of journey, mostly because it links a past to a present, and justifies the present situation in which a narration takes place. What is more, this metaphor seems to be most suitable for stories where the autobiographer tells of his or her youth. These can be compared to adventure or quest narratives. Egan points to the archetypal, mythical origin of this metaphor, since almost the same pattern of plot has been elaborated on by Joseph Campbell in The Hero with a Thousand Faces (1968) and by Vladimir Propp in Morphology of the Folk-Tale (1968). The formula is present in the rites of passage: first there is the necessary separation from the well-known, paradise-like world and family, solitude, then the initiation involving struggle with hardships, appearance of a guide who helps, and a trial—symbolic death and rebirth, so that the changed, mature hero can finally return to the old world (Egan 107).

When looking at the structure of Raal's account the same pattern is surprisingly strictly observed. The young protagonist is forcibly removed from her home, her farm which she describes as a paradise, a place which was for her "almost sacred" (Raal, Lady 6), and her quest starts. The past is idealized and the bliss of her life on the farm is contrasted with the violence and destruction of the war. This constitutes a frequent motif in other personal texts referring to the war. ${ }^{1}$ The war marks also the moment of personal maturation after which the return to the original state of innocence is impossible. Furthermore, nostalgia and an almost obsessive preoccupation with the past, as well as the attachment to the farm constitute recurring motifs in South African prose, written both in Afrikaans and English. ${ }^{2}$ They are most prominent in such genres as the historical novel (Francken \& Renders 197) and the plaasroman, the farm novel (Coetzee 63-81, Van Coller 197-208).

In accordance with the model adventure plot Raal-the protagonist has to fight against the odds, is confronted with the harsh reality of the war, violence and death. Yet, she meets a helper, the good British, Captain Reed, who gives her advice and offers some comfort. Then she is imprisoned and falls seriously ill, barely escapes death. After the war she returns to the farm and reunites with her loved ones, yet, because of her experiences, she is no longer an innocent child. Such a reading may suggest the story's didacticism, and thus corresponds with Raal's foreword to the memoir where she defines its addressee-young generations.

\section{First publication}

As soon as the story was made public, it instigated a heated discussion on BritishAfrikaner relationships. Jaap Steyn in Trouwe Afrikaners (1987) points out that the uneasiness around the memoir was the first big polemic around the concentration camps issue where a witness, and at the same time a survivor, occupied the central place and actively took part in the discussion. However, this was not the very first 
incident of an agitated exchange in the press around these thorny issues. It was to a great extent due to Emily Hobhouse that already during the war the topic of horrifying conditions in the camps was brought into the public debate in England. ${ }^{3}$ The argument continued also after the war was over, both in England and in Africa. For instance in 1928 a polemic in the newspaper Die Volksblad broke out, after Arthur Conan Doylebest known as the creator of Sherlock Holmes, less as a most devoted supporter of British imperialism-publicly stated that Vrouemonument, the women's monument, in Bloemfontein, which commemorates sufferings and deaths in the concentration camps, is a lie. Furthermore, in the 1930s the periodical Die Huisgenoot published a series of testimonies of fighters and non-combatants. Even though women and children were given a chance to speak-yet, only those who spent the time of the war outside the camps. Steyn sees the explanation for this in the fact that Die Huisgenoot wanted to avoid political involvement, and the controversial and painful issue of the camps definitely was political ("Sarah Raal”).

Sarah Raal, then as mevrou Snyman, ${ }^{4}$ first made her war memories public as a series of articles which appeared in Die Burger from 5 December 1936 to 6 February 1937. The first book edition of the memoir was published in 1938 by the Nasionale Pers and stirred up a commotion. One British-oriented reader of The Cape Argus wrote a letter to protest that the book is highly offensive to the British, and described Met die Boere in die Veld as "one of the vilest books [he] has ever read [...]. From cover to cover it vilifies the British in the most outrageous fashion and attributes to them all sorts of crimes and atrocities" (qtd in Steyn, Trouwe 192).

The book contains descriptions of plundered and destroyed farms, of cattle being cruelly slaughtered and of ruthless treatment of people in the internment camps, thus things which had been common also in other war accounts. Yet, there is one particular piece of text which started a heated discussion, namely: "There was just as much senseless murder going on in the camps. Here finely ground glass and vitriol were

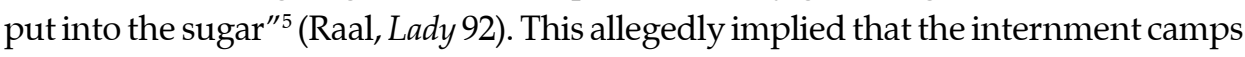
were set up with a view to a conscious and deliberate extermination of the Boers.

On the $5^{\text {th }}$ of August 1938 the daily The Cape Argus published an interview with Raal (which was also quoted by other papers such as Die Oosterling and Die Transvaler). Raal, when asked about the infamous sentences, answered that: "Yes, I saw glass and vitriol with my own eyes. The same observation is also to be found in other books." ${ }^{\prime 6}$ Following the interview Raal received phone calls with threats from various people, and a public debate in the press continued.

The Cape Argus published a major article against the book, and The Eastern Province Herald appealed even to the government to ban the book altogether. Afrikaans papers, on the other hand, received lots of letters from people who survived the camps and wanted to share their recollections. Many of them confirmed what Raal wrote about vitriol in sugar. At the same time some English readers of The Cape Argus negated even 
the existence of the camps as such. In Die Burger on $10^{\text {th }}$ of August 1938 the editorial expressed how outrageous it was to undermine the history of those who went through the camps. Many readers sent their contributions to stress the importance of memory as a basis for continuity and national unity (Steyn, "Sarah Raal").

\section{Raal's foreword to her book}

Raal herself preceded her account with the foreword in which she states the purpose of the publication. In a clearly patriotic mode Raal emphasises the importance of her memories and her singular life for the future generations. This way she defines the collective addressee of the book: "My hoop en verwagting is dat dit die moeite werd sal wees en daartoe sal bydra om die vaderlandsliefde en volksbewussyn by ons jong geslag aan te wakker en die bande nouer te trek wat ons bind as 'n Afrikanervolk" (Raal, Boere [1938]): Voorwoord). ${ }^{7}$ Additionally, Raal explains why she decided to make her life story public: “Na aanleiding van talryke versoeke van vriende en ' $n$ mate van pligsgevoel teenoor my volk, en verder te voldoen aan die begeerte van my kinders, boekstaaf ek hier my persoonlike wedervarings en herinneringe gedurende die Tweede Vryheidsoorlog" (Raal Boere [1938]: Voorwoord). ${ }^{8}$

It may seem as if she wanted to stress beyond all doubt that the decision to publish was not provoked by her egoistic need to become famous, but that she felt obliged to her people. Annemarié van Niekerk (117) points to the fact that in the $19^{\text {th }}$ century professional writing and other sorts of activities in public sphere were deemed inappropriate for a decent lady. This may partially explain why the author felt it necessary to explain her decision, and shift the emphasis onto her role within a social group.

But Raal shares so expressed feeling of duty towards her volk with other authors of personal texts from this period, for instance with Maria Fischer or Johanna Brandt. Furthermore, these authors deny their artistic claims by stressing the personal nature of their work. At the same time, this seems to correspond with the urge to emphasise the text's veracity, which is also a common characteristic of all personal documents in question. ${ }^{9}$ The simplicity of the text, and author's lack of ambitions may testify to the truthfulness of the account. A writer who is incapable of composing more sophisticated forms cannot be capable of making up a story.

\section{The 1938 edition vs. 2000 editions}

\section{The role of the new introduction}

In 2000 the book came out in two language versions-a reprinted Afrikaans one and the first edition ever in English. In the 1930s it was issued by the Nasionale Pers, a publishing house dedicated to the Afrikaners' national and cultural goals, and instrumental to the ideas of Hertzog's nationalists (Stanley and Dampier 508) in the 
context of the Great Trek centenary celebrations and Afrikaners' national consciousness awakening. The new editions in turn came into being thanks to The Stormberg Publishers, a private initiative of Trevor Emslie, professionally a tax law specialist from Cape Town. His publishing house introduces itself on its webpage as "proudly regional, publishing books embodying the romance of the beloved country, expressing the soul of South Africa" (Cederberg Publishers) $\cdot{ }^{10}$ The initiative started with the publication of a single volume of Deneys Reitz trilogy: Commando, Trekking on and No Outspan collectively entitled Adrift on the Open Veld, to coincide with the Anglo-Boer War Centenary. The publisher has in the meantime changed its name, and now as The Cederberg Publishers sells a couple of titles concerning the war, such as Songs of the Veld, a compilation of anti-imperialist protest poetry, two language versions of Raal's memoir, as well as a historical novel The Valley by C. Louis Leipoldt, and several other titles which express "the soul of South Africa" (Cederberg Publishers). In an interview in a legal periodical Trevor Emslie explains plainly the motivation for such activity as his personal love for truly South African books and good stories, and declares his wish to keep them still available to modern South African readers ("Taxman" 49). Different characters of the two publishing houses responsible for the publications of 1938 and 2000 respectively correspond with different characters of the centenaries of these two events which have been crucial for the Afrikaners' history, as discussed later in this paper.

The discrepancies between the 1938 and 2000 editions are conspicuous. The most important change is the addition of the above-mentioned additional introduction, because it significantly modifies the reading of the whole account. The 1938 edition came out with only Raal's own foreword. Taken into account the circumstances of the publication-the complex social and economic transformations in the 1930s and 1940s - this foreword directs the reader to an interpretation within the nationalist paradigm.

The transformations encompassed cultural, social and economic domains. The Anglo-Boer War was a devastating experience for the Afrikaners. It brought destruction of farms and impoverishment, the problem described as "poor whiteism" (Giliomee, "Die Afrikaners"). Many poor and unskilled people moved to cities hoping for a better life and work, but ended up living in extreme poverty. The gradual improvement of the social and economic situation happened to go hand in hand with the awakening of the national consciousness in the Afrikaners. The Great Trek centenary celebrations, along with the general mood of nationalist enthusiasm formed a breeding ground for the ideas expressed by for example J. D. Kestell, an influential clergyman from Bloemfontein and a columnist for the newspaper Die Volksblad. He advocated a cooperation and a strong feeling of national unity as the only way out of the economic crisis (Giliomee, "Die Afrikaners"). The efforts to elevate Afrikaans from the role of an oral medium to the status of the official language of education and state started in the 
years 1903-08 and were already in full swing in the 1920s, yet their consequences in the 1930s and 1940s cannot be overestimated (Dampier 36).

Thus the economic mobilisation ran parallel with the creation of a distinct nation with its own language, history and culture, which resulted in the Afrikaners' "invented tradition". This term refers to traditions which "establish themselves with a great rapidity" and which involve "a set of practices, normally governed by overtly or tacitly accepted rules and of a ritual or symbolic nature, which seek to inculcate certain values and norms of behavior by repetition, which automatically implies continuity with a suitable historic past" (Hobsbawm 1). In this case it involves the interpretation of the Afrikaners' history as a fulfilment of a divine plan reminiscent of the biblical story of the chosen nation (Moodie 11).

When Raal's introduction and her whole account are read within such a context, the national cause indeed comes into the foreground. Thus Raal gives an impression of a brave woman who dedicated her life to her people, and who fought hand in hand with her brothers for the future of the nation. The reader perceives her as a heroine, as a fighter for her country and a member of a community.

Yet, the addition of the new introduction to the 2000 editions causes a distinctive twist in reading, so that one may even venture to say that it reinvents the heroine. As Helen Dampier notices the new introduction written by Anne Emslie-not surprisingly Trevor Emslie's wife at that time (Graaff)—eulogizes Raal as a proto-feminist who transgressed gender roles, and who was admired by her people and despised by the enemy. It presents Raal as a strong woman who suffered in most inhumane conditions, when she introduces her as a heroine who "was mercilessly interrogated and was subjected to unspeakable harshness of solitary confinement, which nearly killed her" (in Raal, Lady 1). Furthermore, Anne Emslie stresses that the book exposes the destructive face of warfare (in Raal, Lady 2). Focusing on this humanitarian aspect, Emslie points out that the Anglo-Boer War was the first total war where a civilian population was involved. Drawing attention to this fact, she reframes the reading of the book, so that the account can be grasped within a more universal framework of a pacifist protest against suffering of innocent people who got entangled in a political conflict.

She refers to a stereotype which presented the War as an exclusively man's business by pointing out that an "unwritten code" of gentlemen was broken:

[T] he Anglo-Boer war broke many previously held rules of warfare. A new era had broken loose, one in which the British military forces were no longer simply engaging in the active fighting force of the Boers, but were in truth waging a war against the entire Boer population. The women, by virtue of their widespread detention, were pulled directly into the arena of the conflict, and an unwritten code was thereby broken. The war was not only a man's war (Emslie in Raal, Lady 2). 
Emslie tries to sketch what she assumes to be an unbiased and fuller picture of the war, which would form a background against which the lot of Sarah is presented. She states that the war did involve all people regardless of their "race and creed, although the Boers initially viewed the conflict as a white man's war" (Emslie in Raal, Lady 3). As Dampier suggests, this statement fits into the "'new nationalism' paradigm which depicted the war as an instance of the 'shared suffering' of Boers and black people at the hands of the British" (Dampier 365).

Perhaps a new myth is in the making in which the shared experience of 'atrocities' at the hands of an alien Empire and its ruthless generals and uncaring bureaucrats is pressed into service to promote bi-racial nationalism [...]. If such an approach requires omission of inconvenient facts, there should be no surprise in that at all. (Cuthbertson and Jeeves 5)

In her attempt to do justice to the history, she adds that the black people were involved on both sides of the conflict, some remained loyal, some defected to the British, and doing so she tries to make up for previous readings of the book as an allegedly racist account. The 1938 publication was widely read as expressing clearly anti-black sentiments (Dampier 362). The book contains such episodes as for instance a vivid description of the shooting of a black murderer of one of the Boer fighters from her commando, Japie.

Yet, Emslie insists that the blacks were neither good nor bad, but their cases should be looked into individually, and such a picture can be found in Raal's book. Neither did the Boers form a uniform group. Apart from the brave and loyal, there were hensoppers (the Boers who surrendered to the British to protect their property) and joiners (those who joined the British and fought for them). These people were viewed by the fighting Boers as traitors and despised by them.

In an effort to shape a more nuanced picture Emslie points out that even some British officers were capable of more sympathetic behaviour, and not all of them were cruel. And indeed the memoir describes Sarah's encounter with one Captain Reed who admitted that he admired her for her courage and attitude. What is more, Sarah refers to him as "my English friend" (Raal, Lady 83).

Emslie states that the Anglo-Boer War has left "deep scars on the psyche of the Boer people" (in Raal, Lady 3), and that the rise of Afrikaner nationalism is rooted there. She observes that Raal's own foreword to the book is good evidence of this fact. To give a more universal dimension to the book, she goes on to say that stories like this by Raal, among others, and "of subsequent atrocities in South Africa and elsewhere in the world" (Emslie in Raal, Lady 3) still live in the present and remind us of the past. It is their role to keep the memory of "acts of barbarism and betrayal" (in Raal, Lady 3) alive among the people. Emslie sums up that Raal told her story so that an important lesson of history is not forgotten. 
Trying to convince the reader that the account is an authentic, nuanced war story, she shapes the character of Raal as a real person, not a monolithic patriotic figure that she was modelled to be in the 1938 edition. One should not overlook that even when Sarah impertinently answered back British interrogations, deep down she was an anxious girl. She hated the British but acknowledged the friendship of Captain Reed, despised the Black farm workers who betrayed her, but loved the loyal ones, and loved her family and the farm which was "almost sacred" (Emslie in Raal, Lady 6) for her. All in all, Emslie gives a picture of a brave country girl who can be appealing and convincing to the reader so that they can easily sympathise with her.

All above-mentioned manoeuvres seem to be justified. Assuming that every book and every story is governed by the laws of the market, the old story needed to be refreshed to become again palatable to a modern public. People may no longer be willing to read stories in the same mode as in the 1930s when Afrikaner nationalism was rising. Personal narratives focusing on "martyrology" and presenting the war as a foil against which God reveals his plan with regard to the Afrikaners as the chosen nation (Moodie 11) may seem outdated. The tale needed to be modernized according to the $21^{\text {st }}$ century fashion. The added introduction overshadows Raal's original foreword, and places the book within the modern feminist and pacifist discourses.

\section{"To the memory of all the women of South Africa" - dedication}

Another difference is the dedication which appeared in the editions of 2000: "This publication is dedicated to the memory of all the women of South Africa who endured suffering and hardship during the Anglo-Boer War" (Raal, Lady). Worth noticing is the fact that the book is dedicated to all women of South Africa, so not only to Boer/ Afrikaans ones. This way-similarly to Emslie's introduction-it is stated that the war was a traumatic experience for all people, regardless of their race. Dampier suggests that due to such operations the interpretation of Raal's story is displaced from its original context and is subordinated to the creation of a "new nationalism". Within this scheme the sense of South African nationhood is built on shared sufferings of the Afrikaners and the black people of Africa (Dampier 369-70). This new doctrine can be viewed as opposed to the apartheid which was the white's "survival strategy" (Giliomee Biography 221, McClintock 68), necessary for the scattered Boer community to get through hard post-war times.

Read in changed circumstances, the book is deemed to reveal the "real" version of history (Dampier 369-70). This encourages the reading within a more universal framework of pacifism and feminism. The dedication places the work within a panAfrican context, a new mode of thinking which presents South Africa as belonging not only to the Afrikaners, but to all other races as well. Similarly, the translation into English opens the previously exclusively Afrikaans history to a reading within a 
broader context, since English is a language understood by a multi-national public, in contrast to Afrikaans whose speakers form a considerably smaller group.

The insistence on the common involvement of all racial groups of South Africa was symptomatic of the official celebrations of the Anglo-Boer Centenary. Since the celebrations took place when South Africa had a black, post-apartheid government, the authorities sought to fit in into the history of a conflict between two white peoples (Grundlingh 360), which turned out to be rather problematic. The official commemorations had originally been planned to take place in the Free State, in a large sports stadium in Bloemfontein, yet the authorities shelved the idea for fear that the audience might not be numerous enough to fill the space (Grundlingh 362). Eventually the celebrations took place in the small town of Brandfort, a site of graves of Boer and British fighters and of a black concentration camp. The crowd which gathered on the $9^{\text {th }}$ October 1999 at Brandfort turned out to be predominantly black. Many of the people arrived only to see President Mbeki; and some of them greeted him with placards and shouts urging the "second black president to alleviate the poverty in Brandfort" ("Party Bly Weg"). As could have been clearly observed, the majority of ordinary black South Africans had little knowledge of the Anglo-Boer War (Grundlingh 367).

In his official commemoration speech Mbeki emphasised that all who suffered and fell should be honoured; he stressed the importance of black participation in the conflict and pointed to the need of remembering the past as an important history lesson and contribution to the creation of a new harmonious nation (Grundlingh 364).

Thus the commemorations of the Anglo-Boer War took a completely different shape than the centenary of the Great Trek in the 1930s. While the Great Trek celebrations were an all-encompassing event with the whole spectacle of the ossewa passage from town to town, the Anglo-Boer War commemorations concentrated around private or local initiatives. Local events which were organised varied in format, ranging from exhibitions and lectures to community barbeques and dances. Families were visiting graveyards and collecting all sorts of material related to the war, such as personal anecdotes and souvenirs (Grundlingh 372). Stormberg Publishers, a family and friends run publishing house which issued the renewed editions of the book by Raal, can serve as an example of this trend.

The revived interest in the war manifested itself in the growth in the number of publications on war-related topics and reprints of old stories, such as the discussed book by Raal. Publications involved personal accounts, fiction and plays. A television documentary Verskroeide Aarde (or Scorched Earth) was released and various exhibitions in art galleries organised (Grundlingh 373). 
2000 English edition vs. 2000 Afrikaans edition

\section{The title}

Interesting differences may be observed also between the two 2000 editions. Firstly, the title of the English version is not the literal translation of Met die Boere in die Veld. It is not "With the Boers in the Veld" but The Lady who Fought. Furthermore, the subtitle A Young Woman's Account of the Anglo-Boer War is more informative than the Afrikaans one (Die Ervarings van die Skryfster, literally "The Experiences of the Writer"), and offers guidance into the subject matter, so that the reader knows what conflict the book refers to.

Additionally, this changed title puts the emphasis on the heroine herself. This is in line with Emslie's introduction where Raal is presented as a remarkable individual and a proto-feminist, a woman ahead of her times, because she is extraordinarily active and goes against the grain shaking off her stereotypically imposed gender role. Apart from that, she is called a "lady", which directly refers to the discourse of (British) gentlemen. This way she is presented as a noble person who is worthy of respect, in contrast to the stereotypical image of a Boer woman propagated in many wartime British propaganda papers. They explained high mortality rates in the camps as the consequence of Boer women's "filthy habits" and backwardness of their heeling methods. For instance in The Times issue from $19^{\text {th }}$ June 1901 one can read that " [Boer women] are absolutely without appreciation for the necessity of careful sanitary cleanliness. The women take but small care of their children" (qtd in Krebs 50). Thus, for an English-speaking public Raal gets promoted to the rank of a noble individual.

It is worth mentioning that the English title comes from an episode where Captain Reed reads a letter which contains the memorable phrase describing Sarah as "the lady who fought" (Raal, Lady 77). The words turned out to be significant enough to become the title of the English version of the book. This way it is Sarah as a character who now becomes the crucial component of the whole story, in contrast to the Afrikaans title Met die Boere in die Veld. Die Ervarings van die Skryfster where it seemed more important that Raal was one of many fighters for the common cause. The second part of the title stresses that the book contains experiences of the author, so the value of the book as a historical document comes to the foreground. The insistence on a testimony's veracity seems to be characteristic for women's Boer War accounts (Ryan 10).

\section{Translation and ideology}

The English version is interspersed with a number of Afrikaans words. Apparently the translator found it necessary to leave them, so that the book could retain its original flavour. Yet, to make the text broadly accessible to all audiences, this edition contains a glossary which explains the original Afrikaans terms. 
However, there is one particular Afrikaans word which was translated, and whose translation was a politically motivated choice. The word in question is kaffir. Dampier notices that the publication of various language versions involves replacing originals by politicised translations; " $\mathrm{t}$ ]ranslation transmutes the messy real-life accounts of Boer women into ideologically clear-cut testimonies" (Dampier 367). Thus translation is more than just a language issue, because it means also replacing real memory with an ahistorical creation (368). In the Afrikaans editions the word kaffir is frequently used as a term referring to indigenous inhabitants of Africa. ${ }^{11}$ Nowadays the word kaffir is perceived as an extremely offensive term. It needs to be observed that its use has been strictly linked with history and political context, and as such has got especially burdened with negative connotations during the apartheid time. The word itself comes from Arabic, and originally denoted a non-believer or infidel, someone who rejects or is closed to Islam, a non-Muslim. Ironically, later on European settlers took this word over, and started to use it to refer to the Xhosa people (Baderoon).

Yet, in the English translation by Karen Smalberger the more politically correct "African" is used instead. Even though both terms are burdened with political and historical connotations, "African" refers most of all to Africa as a geographical territory, and as such denotes ethnicity. Consequently, although not absolutely ahistorical and apolitical, definitely is not as controversial as the word kaffir. Notably, in the Afrikaans version of the book the offensive term remains, which may seem inconsequent, taken into account that the Promotion of Equality and Prevention of Unfair Discrimination Act of 2000 declares the use of words such as kaffir, hotnot and coolie as hate speech (BBC News). The publisher, Trevor Emslie aware of the offensive nature of the word, explains his decision by the fact that the translation was a new rendering in other language, and thus a new text which only came into being in 2000. Yet, when it comes to the Afrikaans re-edition he did not feel that he had the right to alter the original, already existing and published text (Trevor Emslie).

\section{Illustrations}

As Genette proposed, even before the reading starts books are already communicating a message to the reader, which takes place by means of the paratext. To the realm of the paratext belong also non-textual components of the book, such as illustrations. They are a part of the machinery employed to produce the effect of the real, and have an impact on convictions the reader formulates in the process of reading.

Starting with the cover, in both 2000 editions there appears the same photo of a woman on a horseback wearing a hat typical of the Boer commando fighters, a belt of ammunition and a rifle. In the background there is a vague image of a camp somewhere in the open flat field (the same image appears later in the book described as the "Bird Cage"). The reader does not know who the woman is, although it may be surmised 
that it is the young Sarah. However, the photo is posed, so it does not seem likely that it actually is the heroine. In fact, the picture turns out to be found in other book as well, namely With the Boer Forces, written by Howard C. Hillegas, a war correspondent of The New York World, and published in 1900. The lady in the photo is supposed to be Mrs Otto Krantz, one of the women who were given the government's sanction to accompany their husbands in the field during the Natal campaign. Mrs Krantz is believed to have participated in the battle by her husband's side. Since she is a Boer woman who was on the battlefield, her image matches Raal's account, so it was simply borrowed. Further, the reader sees the frontispiece with a photo of a young woman, who is more likely to be Sarah in her youth. On the next page there is a map of the Orange Free State and surroundings, which is meant to denote the geographical location of the story, and at the same time to confirm the story's authenticity. Above Raal's foreword from 1936 there is another image of her, this time as a middle-aged woman. Now the reader can see the person who addresses them, and imagine that this plump bespectacled lady used to be the young, rebellious Sarah, who now recalls her adventurous youth, and tells her grandchildren a tale to be remembered. This, in turn, suggests the story's didactical reading.

Apart from these, the book contains another three photographs, each with a caption. On p. 6 there is a photograph of Sarah's family farm: "Olijvenfontein, the farm on which Sarah Raal was born, and which to her was 'almost sacred'". Then on p. 32 a photograph of "Springfontein, the first concentration camp to which Sarah Raal was sent and from which she escaped"; and on p. 89 a photograph of "A 'Bird Cage' similar to that in which Sarah Raal almost met her end". All these illustrations seem to guide the reader into the old world and at the same time convince and confirm that the story is real-everyone can see the photographs. This is in agreement with what Roland Barthes wrote in Camera Lucida: "there is superimposition here [in the photograph]: of reality and of the past" (Barthes 76), and furthermore: "what I see has been here [...], it has been absolutely, irrefutably present, and yet already deferred" (Barthes 77).

Yet, the seemingly straightforward relationship between the story and photographs may be misleading. Photographs are not samples of the past, neither immediate recordings of it, but a new product into which a recorded past reality has been transformed (Zajas 102). To a great extent it depends on the reader to name what they see. Even if one agrees that a photograph is a document, at the same time it is open to build a narration around it, to adorn it and add a symbolical dimension (Hirsch 117). This way a photo is a perfect instrument for the construction of "post-memory", that is the memory of a traumatic past for those who did not personally participate in it, yet would like to incorporate it as a part of their collective memory (Zajas 121).

When it comes to the edition from 1938, the same photograph of the farm Olijvenfontein can be spotted, yet further there are only drawings. These include the cover art depicting a girl on a horseback. Later in the book there is an image of the girl 
galloping on her horse, and another of her pointing a rifle at a soldier. The drawings refer directly to Sarah's adventures as described in the memoir; below each drawing there is a relevant quote as a caption. The over-evident pictures make the book look like a youth adventure novel. Having taken this into account the book indeed reads like an "over-romanticised cow-girl story" (Swanepoel 24).

\section{Conclusion}

The above discussion shows that parallel to the seemingly simple text, a mere adventure cow-girl story, runs a story of its translation, re-editions and changing readings. The text can be transformed and recreated so that it responds to and matches a given political context and the needs of the readership at a given moment. These are, at the first sight, minor modifications, such as the addition of an introduction or use of different vocabulary, yet they turn out to have a decisive influence on the reading process and interpretation. Thus the book when published and read in the 1930s was predominantly instrumental to Afrikaner nationalist propaganda, which was clearly stated by the author herself in her foreword.

Additionally, the book can be read as expressly didactical and attractive to the young reader, mainly because of suggestive drawings, which give the account an aura of an adventure story. The heroine in turn, the brave young Sarah, becomes a role-model for new generations of patriotic youth.

The 2000 editions read differently, though. Firstly, because of the editor's introduction, which shifts the reading from the Afrikaner national cause to more universal patriotism and pacifism, showing war as a destructive force which is equally devastating to all people regardless of their race. Even more significant is that Raal is presented as a proto-feminist, which accentuates modern preoccupation with gender issues in public life and literature. The translation of the problematic word kaffir as "African", makes the English book more politically correct, and consequently suitable for a broad English-speaking public. Inclusion of photographs, instead of drawings, is supposed to emphasise that the account-regardless of its language-is a reliable document, meant to preserve the memory of the traumatic past and of the people whose bravery serves future generations.

In all cases-whether the book is read as a nationalist propaganda text, or a simplified didactical cow-girl adventure story, or an account of a feminist, a strong woman who was ahead of her times, or a pacifist protest against the war-the book belongs to the realm of popular literature. Within this paradigm its readings and popularity are dependent on the readership, "for books directed at the mass market must confirm-not contradict-popular perceptions, if they are going to have wide appeal and achieve sales" (Rice xxi). The suggested readings of Raal's book constitute responses to current extra-textual circumstances and readers' needs. 


\section{Notes}

1 For instance in an other personal document, a diary by Maria A. Fischer Tant Miem Fischer se kampdagboek the author states that before the war her life of a typical Boer woman with a traditionally big family was maybe monotonous, but ultimately happy (Fischer 5).

2 Apart from nostalgia and longing for the lost arcadia, other frequently employed motifs in the plaasroman are utopia and dystopia, see for instance: Jerzy Koch (Outsider), or his article "Rondom de Ander in Na die geliefde land van Karel Schoeman".

3 For more on the press debate in Britain see Krebs (32-54).

4 Similar choices between the maiden name and the married name was made by an other wellknown author of autobiographical texts from that period, Johanna Brandt-van Warmelo. This may suggest the writer's attempt to make a distinction between her "self" in the past and her "self" at the moment of writing up her memories and publishing them. (For the implications of this issue see Drwal.)

5 "Hier moor hulle maar net so onder die mense. Hier word fyngemaalde glas en vitrioel in die suiker gegooi." (Raal, Boere [2000]: 93)

6 "Ja, ek het die glas en vitrioel met my eie oë gesien. Dieselfde bewering word ook in ander boeke gemaak." (qtd in Steyn Trouwe 192)

7 "My hope and expectation is that the effort will prove worthwhile, and that it will contribute to an awakening sense of patriotism and nationhood in the younger generation, and strengthen the ties which bind us together as an Afrikaner people." (Raal, Lady 5)

8 "Prompted by the requests of many friends, a sense of duty to my people, and to satisfy the wishes of my children, I have recorded my personal experiences and recollections of the Second War of Independence" (Raal, Lady 5).

9 Similar insistence on the text's veracity appears in Maria A. Fischer's Tant Miem Fischer se kampdagboek and Johanna Brandt's Die Kappie Kommando. Both authors in the introductions to their books emphasise the personal character of their accounts. Fischer plays down herself by stating that her life has always been too uneventful to be a suitable material for a book. Brandt stresses that she is not writing according to an officially prescribed line, but relies solely on her notes and memory, which may be read as her attempt to side-step possible accusations of providing incorrect or inaccurate data.

10 This description seems to allude to the Proudly South African Campaign aiming at the promotion of various South African goods and services. Significantly, apart from its economic objectives, the campaign addresses feelings of patriotism and national pride.

11 "The use of the term dates back to the 16th century; from Arabic qafir 'unbeliever, infidel, impious wretch', with a literal sense of 'one who does not admit the blessings of God', from kafara 'to cover up, conceal, deny'. Technically, 'non-Muslim', but in Ottoman times it came to be used almost exclusively for 'Christian'. Early English missionaries used it as an equivalent of 'heathen' to refer to Bantus in South Africa (1792), from which use it came generally to mean 'South African black' regardless of ethnicity, and to be a term of abuse since at least 1934" (Online Etymology Dictionary).

\section{Works cited}

Baderoon, Gabeba. "The Provenance of the Term 'Kaffir' in South Africa and the Notion of Beginning." 24 Apr 2012. <http://web.uct.ac.za/depts/religion/documents/ARISA/2004_MS4.pdf>.

Barthes, Roland. Camera Lucida: Reflections on Photography. New York: Hill and Wang, 1981.

BBC News. "South Africa bans discrimination." 26 Jan 2000, 20 Mar 2012. <http://news.bbc.co.uk/1/hi/ world/africa/619337.stm>.

Beukes, Lauren. Maverick: Extraordinary Women from South Africa's Past. Cape Town: Oshun Books, 2004.

Bradford, Helen "Gentlemen and Boers". Eds. Gregor Cuthbertson, A M. Grundlingh, and MaryLynn Cuthbertson. Writing a Wider War: Rethinking Gender, Race, and Identity in the South African War, 1899-1902. Athens: Ohio UP, 2002: 37-66.

Campbell, Joseph. The Hero with a Thousand Faces. Princeton: Princeton UP, 1968.

Cederberg Publishers. 15 Sept 2012. <http://www.cederbergpublishers.co.za/\#panel1-2>.

Coetzee, J. M. White Writing: On the Culture of Letters in South Africa. New Haven: Yale UP, 1988.

Coullie, Judith L. The Closest of Strangers: South African Women's Life Writing. Johannesburg: Wits UP, 2004.

Cuthbertson, Greg, Alan Jeeves. "The Many-Sided Struggle for Southern Africa, 1899-1902." South African Historical Journal, 41.1 (1999): 2-21. 
Dampier, Helen. Women's Testimonies of the Concentration Camps of the South African War 1899-1902 and After. PhD diss., Newcastle University, 2005.

Drwal, Małgorzata. Teksty intymistyczne kobiet z okresu wojny anglo-burskiej (1899-1902). Historia - literatura - gender. PhD diss. in progress. University of Wrockaw, Poland.

Emslie, Trevor. "Met die boere in die veld". Personal correspondence to the author. 16 Nov 2012. E-mail.

Francken, E., L. Renders. Skrywers in Die Strydperk: Krachtlijnen in de Zuid-Afrikaanse Letterkunde. Amsterdam: B. Bakker, 2005.

Genette, Gerard. Paratexts. Thresholds of Interpretation. Cambridge UP, 2001.

Giliomee, Hermann B. The Afrikaners: Biography of a People. Charlottesville: U Virginia P, 2003.

. "Die Afrikaners van 1910 tot 2010." 29 Jun 2012. Universiteit Gent, Seminarie Afrikaans. <http:/ /www.seminarie-afrikaans.ugent.be/file/7>.

Graaff, Anne. "Met die boere in die veld". Personal correspondence to the author. 16 Nov 2012. E-mail.

Grundlingh, Albert. "Reframing Remembrance: the Politics of the Centenary Commemoration of the South African War of 1899-1902." Journal of Southern African Studies 30.2 (2004): 359-75.

Hillegas, Howard C. With the Boer Forces. London: Methuen, 1900.

Hirsch, Marianne. "The Generation of Postmemory." Poetics Today 29.1 (2008): 103-28.

Hobsbawm, E. J., and T. O. Ranger. The Invention of Tradition. Cambridge UP, 1983.

Koch, Jerzy. Outsider Onder De Zijnen: Vormen Van Xenofanie in De Afrikaanse Roman. Wrocław: Wydawnictwo Uniwersytetu Wrocławskiego, 2002; also: <http://www.dbnl.org/tekst/koch003outs01_01/ koch003outs01_01_0005.php>.

. "Rondom de Ander in Na die geliefde land van Karel Schoeman". Stilet XIV.2 (2002): 144-64.

Krebs, Paula M. Gender, Race, and the Writing of Empire: Public Discourse and the Boer War. Cambridge: CUP, 1999.

McClintock, Anne. "Family Feuds: Gender, Nationalism and the Family." Feminist Review. Nationalisms and National Identities 44 (1993): 61-80.

Moodie, T. D. The Rise of Afrikanerdom: Power, Apartheid, and the Afrikaner Civil Religion. Berkeley: U of California P, 1975.

Muller, Colin, Madeleine Wright, Penny Silva. A Dictionary of South African English on Historical Principles. Cape Town: OUP, 1996.

Online Etymology Dictionary<http://www.etymonline.com/index.php?term=kaffir >

"Party Bly Weg omdat Regering Herdenking Kaap". Die Volksblad, 11 Oct. 1999.

Propp, Vladimir I. A. Morphology of the Folktale. Austin: U of Texas P, 1968.

Raal, Sarah. Met Die Boere in Die Veld: Die Ervarings Van Die Skryfster. Kaapstad: Nasionale Pers, 1938.

. Met Die Boere in Die Veld: Die Ervarings Van Die Skryfster. Plumstead: Stormberg Publishers, 2000.

. The Lady Who Fought: A Young Woman's Account of the Anglo-Boer War. Plumstead: Stormberg Publishers, 2000.

Rice, M. C. From Dolly Gray to Sarie Marais: The Boer War in Popular Memory. Noordhoek: Fischer Press, 2004.

Ryan, Pamela. "Plain Women and Ladies in a Strange Country." Alternation 8.1 (2001): 6-27.

Smith, Sidonie, and Julia Watson. Reading Autobiography: A Guide for Interpreting Life Narratives. Minneapolis: U of Minnesota P, 2001.

Stanley, Liz, Helen Dampier. "Cultural Entrepreneurs, Proto-Nationalism and Women's Testimony Writings: From the South African War to 1940." Journal of South African Studies 33.3 (2007): 501-19.

Steyn, Jaap. "Sarah Raal se dagboek het in '38 herrie onketen." 14 Jan 2012. Die Burger, Erfenis Gered. 6/ 05/2000: 3. <http://152.111.1.87/argief/berigte/dieburger/2000/05/06/3/23.html >.

_. Trouwe Afrikaners: Aspekte Van Afrikaner-Nasionalisme en Suid-Afrikaanse Taalpolitiek, 1875-1938. Kaapstad: Tafelberg-Uitgewers, 1987.

Swanepoel, E. “Ubuntu en Individualisme: Enkele Opmerkings oor die Suid-Afrikaanse Outobiografie." Stilet 8.1 (1996): 20-27.

"The Taxman Cometh, Bearing Books." Advocate 24.2 (Aug 2011): 48-49.

Van Coller, H. P. "Tussen Nostalgie en Parodie: die Afrikaanse Prosa in die Jare Negentig (deel I)." Tydskrif vir Geesteswetenskappe 35.3 (1995): 197-208.

Van Niekerk, Annemarié. "'Finding my own Voice?' Women's Ego Texts from the South African War -A Genre Exploration." Stilet 13.2 (2001): 103-22.

Zajas, Paweł. Jak świat prawdziwy stał się bajka. O literaturze niefikcjonalnej. Poznań: Wydawnictwo Poznanśkie, 2011 